\title{
Food Insecurity and Cardiometabolic Conditions: a Review of Recent Research
}

\author{
Jennifer Te Vazquez ${ }^{1}$. Shi Nan Feng ${ }^{1,2} \cdot$ Colin J. Orr $^{3,4} \cdot$ Seth A. Berkowitz ${ }^{4,5}$ (D) \\ Accepted: 9 June 2021 / Published online: 21 June 2021 \\ (C) The Author(s), under exclusive licence to Springer Science+Business Media, LLC, part of Springer Nature 2021
}

\begin{abstract}
Purpose of Review To understand recent literature that examines associations between food insecurity and cardiometabolic conditions and risk factors. We included original research, systematic reviews, and meta-analyses on the topic of food insecurity and cardiometabolic risk published from January 1, 2017, to December 31, 2020. Editorials, perspectives, and case reports were excluded. After the initial search, 3 reviewers selected studies for inclusion based on relevance and methods. Ultimately, fifty studies were included.

Recent Findings We included 35 studies of adults ( 20 cross-sectional observational studies, 5 longitudinal observational studies, 5 interventional studies, and 5 meta-analyses/reviews). In adults, food insecurity is associated with greater prevalence of overweight/obesity (especially for women). It is also associated with hypertension, diabetes (including worse glycemic control and more diabetes complications), coronary heart disease, congestive heart failure, stroke, and chronic kidney disease. We included 15 studies of children (11 cross-sectional observational studies and 4 longitudinal observational studies). In children, findings were more nuanced, and in particular, many studies did not find an association between food insecurity and overweight/ obesity. However, authors noted that these conditions may not have had time to develop. With notable exceptions, many studies were cross-sectional, and there were few interventions.

Summary There is a robust association between food insecurity and cardiometabolic conditions and risk factors in adults, but the picture is less clear in children. Overt cardiometabolic clinical conditions develop more rarely in children, but childhood experiences may set a trajectory for worse health later in life. Detailed life course epidemiologic studies are needed to better understand this relationship. Future interventions should examine how to reduce the prevalence of food insecurity, and how best to improve health for those who experience food insecurity.
\end{abstract}

Keywords : Food insecurity $\cdot$ Socioeconomic factors $\cdot$ Obesity $\cdot$ Diabetes mellitus $\cdot$ Coronary heart disease $\cdot$ Congestive heart failure $\cdot$ Hypertension $\cdot$ Chronic kidney disease

This article is part of the Topical Collection on Cardiovascular Disease

Seth A. Berkowitz

seth_berkowitz@med.unc.edu

1 College of Arts and Sciences, University of North Carolina at Chapel Hill, Chapel Hill, NC, USA

2 Nutrition Science Program, Gillings School of Global Public Health, University of North Carolina at Chapel Hill, Chapel Hill, NC, USA

3 Division of General Pediatrics and Adolescent Medicine, University of North Carolina at Chapel Hill, Chapel Hill, NC, USA

4 Cecil G. Sheps Center for Health Services Research, University of North Carolina at Chapel Hill, Chapel Hill, NC, USA

5 Division of General Medicine and Clinical Epidemiology, Department of Medicine, University of North Carolina at Chapel Hill School of Medicine, 5034 Old Clinic Bldg, CB 7110, Chapel Hill, NC 27599, USA

\section{Introduction}

Food insecurity is defined as "the limited or uncertain availability of nutritionally adequate and safe foods, or limited or uncertain ability to acquire acceptable foods in socially acceptable ways [1]." In 2019, $10.5 \%$ of US households and $13.6 \%$ of US households with children experienced food insecurity [2]. Food insecurity has been associated with worse health through at least 3 key mechanisms: (1) a nutritional pathway, (2) a compensatory pathway, and (3) a psychological pathway (Fig. 1). In the nutritional pathway, food insecurity is linked to worse diet quality [3, 4]. An important reason for this is that less healthy, highly processed foods, often laden with sodium, added sugar, and saturated fat, can be cheaper on a per calorie basis than healthier foods such as fruits and 


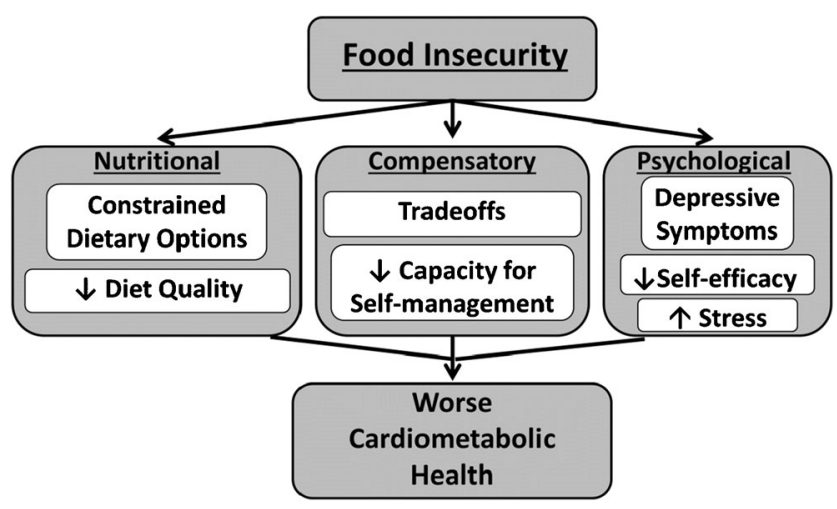

Fig. 1 Conceptual model of the relationship between food insecurity and cardiometabolic health

vegetables, whole grains, and lean protein [5]. Worse diet quality may increase the risk of overweight/obesity, and directly influence development of cardiometabolic conditions such as diabetes. Next, the compensatory actions needed to avoid or mitigate the effects of food insecurity can push individuals towards behaviors that make it hard to achieve or maintain health. For example, food insecurity is often associated with trade-offs that can worsen health, such as needing to forego medications in order to purchase food [6,7]. This can further sap one's capacity for self-management as attention is diverted to deal with other pressing matters. Finally, food insecurity is highly aversive, and is strongly linked to psychological distress, lower self-efficacy, biological markers of stress, and depressive symptoms $[8,9]$. All three of these pathways are particularly salient when considering cardiometabolic health. Cardiovascular disease is the number one cause of death globally; in 2016, cardiovascular disease represented $31 \%$ of all global deaths [10]. As of 2020, approximately 655,000 Americans die from heart disease annualy [11]. Thus, understanding the relationship between food insecurity and cardiometabolic risk has important implications for the public's health.

The purpose of this review is to examine and summarize recent literature on the intersection of food insecurity and cardiometabolic risk. Specifically, we review recent research that examines the association between food insecurity and the following clinical conditions, in adults or children: overweight/ obesity, hypertension, diabetes, coronary heart disease, congestive heart failure, stroke, and chronic kidney disease.

\section{Methods}

\section{Search Strategy and Selection Criteria}

This narrative review includes original research, systematic reviews, and meta-analyses published from January 1, 2017, to December 31, 2020. PubMed, Embase, and Web of Science were searched for cross-sectional, longitudinal, and interventional studies relating food insecurity to cardiovascular disease risk. Search terms included "cardiometabolic risk," "overweight and obesity," "hypertension," "diabetes," "coronary heart disease," "congestive heart failure," "stroke," and "chronic kidney disease" in combination with "food insecurity" or "food security." After the initial search, 3 reviewers selected studies for inclusion based on relevance and quality of methods. Editorials, perspectives, and case reports were excluded. All disagreements were resolved by consensus.

Once studies were selected, we categorized the findings into the following subsections: "Overweight/Obesity," "Hypertension," "Diabetes," "Coronary Heart Disease, Congestive Heart Failure, and Stroke," and "Chronic Kidney Disease."

Regarding classification of food insecurity, the studies in this review tended to use either a dichotomous approach (food secure vs. food insecure) or multiple categories. A common classification for multiple categories included low food security, "reduced quality, variety, or desirability of diet but little or no indication of reduced food intake," and very low food security, "multiple indications of disrupted eating patterns and reduced food intake." We did not find studies that used food insecurity as a continuous variable.

\section{Results}

\section{Adult Populations (Table 1)}

\section{Overweight/Obesity}

The relationship between food insecurity and overweight/ obesity has been widely studied. Though initially thought to be paradoxical, food insecurity may incentivize consumption of cheaper, calorie-dense, nutrient-poor food that provides a plausible mechanism linking food insecurity with overweight/ obesity. Overall, the current literature is consistent with higher BMI and greater prevalence for obesity among adults with food insecurity. The relationship seems to be stronger for women than men. However, this literature is primarily crosssectional, and we did not find interventional studies examining whether addressing food insecurity was associated with weight loss.

A cross-sectional study among 250 participants in Dutch disadvantaged neighborhoods found that food insecurity was associated with obesity in models adjusted for demographics, socioeconomic indicators, and lifestyle factors $(\mathrm{OR}=2.51$, $95 \%$ CI $0.98,6.48)$, but not with overweight $(\mathrm{OR}=1.15$, $95 \%$ CI $0.46,2.85$ ) [12]. Likewise, a study of 146 households agricultural migrant workers in Mexico found that household food insecurity was associated with greater odds of obesity overall $(\mathrm{OR}=5.18,95 \% \mathrm{Cl} 1.37,19.6)$, but that the 
Table 1 Selected characteristics of included studies of adults

\begin{tabular}{|c|c|c|c|c|c|}
\hline Author, year & Study design & Setting & Sample size & $\begin{array}{l}\text { Follow- } \\
\text { up }\end{array}$ & Key findings \\
\hline \multicolumn{6}{|c|}{ Overweight/obesity } \\
\hline $\begin{array}{l}\text { van der } \\
\text { Velde } \\
\text { et al.,2020 }\end{array}$ & Cross-sectional & "Deprived" urban area in Netherlands & 250 & $\mathrm{n} / \mathrm{a}$ & $\begin{array}{l}\text { Food insecurity associated with obesity }(\mathrm{OR}=2.51 \text {, } \\
\text { 95\% CI } 0.98,6.48) \text {, but not with overweight }(\mathrm{OR} \\
1.15,95 \% \text { CI } 0.46,2.85)\end{array}$ \\
\hline $\begin{array}{l}\text { Castañeda } \\
\text { et al. } 2019\end{array}$ & Cross-sectional & $\begin{array}{l}\text { Migrant farm workers in agribusiness } \\
\text { areas of Northwest Mexico }\end{array}$ & 146 & $\mathrm{n} / \mathrm{a}$ & $\begin{array}{l}\text { Household food insecurity associated with obesity } \\
\text { overall (OR 5.18, } 95 \% \text { CI: } 1.37,19.58 \text { ), but } \\
\text { association changes sign between women (higher } \\
\text { risk) and men (lower risk) }\end{array}$ \\
\hline $\begin{array}{l}\text { Caspi et al. } \\
2017\end{array}$ & Cross-sectional & Boston, MA & 828 & $\mathrm{n} / \mathrm{a}$ & $\begin{array}{l}\text { Those experiencing food hardship were more likely } \\
\text { to be obese (RR } 1.17,95 \% \text { CI } 1.07,1.29 \text { ) than } \\
\text { those not experiencing food hardship }\end{array}$ \\
\hline $\begin{array}{l}\text { Ashe and } \\
\text { Lapane } \\
2017\end{array}$ & Cross-sectional & $\begin{array}{l}\text { USA, nationally representative } \\
\text { survey of women age } \geq 40 \text { years }\end{array}$ & 4,672 & $\mathrm{n} / \mathrm{a}$ & $\begin{array}{l}\text { Food-insecure woman had } 1.4 \text { the odds of obesity. } \\
\quad(95 \% \text { CI } 1.22,1.62) \text {. }\end{array}$ \\
\hline $\begin{array}{l}\text { El Zein, et al. } \\
2020\end{array}$ & Cross-sectional & College students at 8 US universities & 683 & $\mathrm{n} / \mathrm{a}$ & $\begin{array}{l}\text { Marginal food security and food insecurity were } \\
\text { associated with } 3.16 \text { (95\% CI: } 1.55,6.46) \text { and } \\
5.13 \text { (95\% CI: } 2.63,10.00) \text { greater odds of obesity }\end{array}$ \\
\hline $\begin{array}{l}\text { Lund et al. } \\
2018\end{array}$ & Cross-sectional & Denmark & 1,877 & $\mathrm{n} / \mathrm{a}$ & $\begin{array}{l}\text { Association between food insecurity and obesity not } \\
\text { significant in adjusted models for women or men }\end{array}$ \\
\hline $\begin{array}{l}\text { Nagata et al. } \\
2019\end{array}$ & Cross-sectional & $\begin{array}{l}\text { USA, nationally representative } \\
\text { survey }\end{array}$ & 14,786 & $\mathrm{n} / \mathrm{a}$ & $\begin{array}{l}\text { In young adults (age } 24-32 \text { years), food insecurity } \\
\text { not associated with obesity in adjusted models } \\
\text { (OR } 1.12,95 \% \mathrm{Cl} 0.97,1.29)\end{array}$ \\
\hline $\begin{array}{l}\text { Moradi et al. } \\
2019\end{array}$ & Meta-analysis & 31 studies from 14 countries & $\begin{array}{l}115,993 \\
\text { (across all } \\
\text { studies) }\end{array}$ & $\mathrm{n} / \mathrm{a}$ & $\begin{array}{l}\text { Adults in food-insecure households are more at risk } \\
\text { of obesity (OR 1.15, 95\% CI 1.06, 1.23). In } \\
\text { food-insecure households, women had a higher } \\
\text { risk of obesity than men (OR 1.26, 95\% CI 1.05, } \\
\text { 1.46). }\end{array}$ \\
\hline $\begin{array}{l}\text { Keenan et al. } \\
2021\end{array}$ & Cross-sectional & UK & 604 & $\mathrm{n} / \mathrm{a}$ & $\begin{array}{l}\text { In structural equation models, food insecurity was } \\
\text { indirectly associated with higher BMI via greater } \\
\text { distress and eating to cope }\end{array}$ \\
\hline \multicolumn{6}{|l|}{ Hypertension } \\
\hline $\begin{array}{l}\text { Nagata et al. } \\
2019\end{array}$ & Cross-sectional & $\begin{array}{l}\text { USA, nationally representative } \\
\text { survey }\end{array}$ & 14,786 & $\mathrm{n} / \mathrm{a}$ & $\begin{array}{l}\text { Food-insecure young adults (aged } 24-32) \text { have } \\
\text { greater odds of hypertension (1.40, 95\% CI 1.14, } \\
1.72 \text { ) compared with food-secure young adults }\end{array}$ \\
\hline $\begin{array}{l}\text { Berkowitz } \\
\text { et al. } 2017\end{array}$ & Cross-sectional & $\begin{array}{l}\text { USA, nationally representative } \\
\text { survey }\end{array}$ & 21,196 & $\mathrm{n} / \mathrm{a}$ & $\begin{array}{l}\text { Age-standardized rates of food insecurity are greater } \\
\text { in participants with hypertension }(14.1 \% \text { vs. } \\
11.1 \%, \mathrm{P}=0.0003)\end{array}$ \\
\hline $\begin{array}{l}\text { Leung et al. } \\
2020\end{array}$ & Cross-sectional & $\begin{array}{l}\text { USA, nationally representative } \\
\text { sample of older adults }\end{array}$ & 2,048 & $\mathrm{n} / \mathrm{a}$ & $\begin{array}{l}\text { Food insecurity not significantly associated with } \\
\text { hypertension }(40.3 \% \text { hypertension among } \\
\text { food-secure adults vs. } 46.7 \% \text { among } \\
\text { food-insecure adults, } \mathrm{P}=0.10 \text { ) }\end{array}$ \\
\hline $\begin{array}{l}\text { da Silva } \\
\text { Miguel } \\
\text { et al. } 2020\end{array}$ & $\begin{array}{l}\text { Systematic } \\
\text { review }\end{array}$ & International & $\mathrm{n} / \mathrm{a}$ & $\mathrm{n} / \mathrm{a}$ & $\begin{array}{l}\text { Direct association between food insecurity and } \\
\text { hypertension after adjusting for } \\
\text { sociodemographic, economic, and lifestyle } \\
\text { characteristics }\end{array}$ \\
\hline \multicolumn{6}{|c|}{ Diabetes mellitus } \\
\hline $\begin{array}{l}\text { Lee et al. } \\
2018\end{array}$ & Cross-sectional & $\begin{array}{l}\text { USA, nationally representative } \\
\text { survey of participants aged } 20-39\end{array}$ & 3,684 & $\mathrm{n} / \mathrm{a}$ & $\begin{array}{l}\text { Significantly greater odds of prediabetes/diabetes } \\
\text { after adjustment for age, sex, and income (OR } \\
1.36,95 \% \text { CI 1.00, 1.85) }\end{array}$ \\
\hline $\begin{array}{l}\text { Walker et al. } \\
2018\end{array}$ & Cross-sectional & $\begin{array}{l}\text { Primary care clinics in the Southeast } \\
\text { United States }\end{array}$ & 615 & $\mathrm{n} / \mathrm{a}$ & $\begin{array}{l}\text { Food insecurity associated with direct pathway to } \\
\text { increased hemoglobin } \mathrm{A} 1 \mathrm{c}(\mathrm{r}=0.66, \mathrm{P}=0.03)\end{array}$ \\
\hline $\begin{array}{l}\text { Murillo et al. } \\
2017\end{array}$ & Cross-sectional & $\begin{array}{l}\text { USA, nationally representative } \\
\text { survey }\end{array}$ & 19,048 & $\mathrm{n} / \mathrm{a}$ & $\begin{array}{l}\text { Food insecurity associated with pre-diabetes in } \\
\text { women (OR } 1.62,95 \% \text { CI } 1.22,2.16)\end{array}$ \\
\hline $\begin{array}{l}\text { Vaccaro and } \\
\text { Huffman } \\
2017\end{array}$ & Cross-sectional & $\begin{array}{l}\text { USA, nationally representative } \\
\text { survey of adults aged } \geq 55 \text { years }\end{array}$ & 3,871 & $\mathrm{n} / \mathrm{a}$ & $\begin{array}{l}\text { Food-insecure men have lower odds of diabetes in } \\
\text { comparison to women (OR: } 0.39,95 \% \text { CI } 0.23 \text {, } \\
0.66 \text { ) }\end{array}$ \\
\hline
\end{tabular}


Table 1 (continued)

\begin{tabular}{|c|c|c|c|c|c|}
\hline Author, year & Study design & Setting & Sample size & $\begin{array}{l}\text { Follow- } \\
\text { up }\end{array}$ & Key findings \\
\hline $\begin{array}{c}\text { Abdurahman } \\
\text { et al. } 2018\end{array}$ & $\begin{array}{l}\text { Meta-analysis } \\
\text { of } \\
\text { cross-- } \\
\text { sectional } \\
\text { studies }\end{array}$ & International & $\begin{array}{l}\text { 55,353,915 } \\
\text { (across all } \\
\text { included } \\
\text { studies) }\end{array}$ & $\mathrm{n} / \mathrm{a}$ & $\begin{array}{l}\text { Household food insecurity significantly associated } \\
\text { with odds of type } 2 \text { diabetes (OR } 1.27,95 \% \text { CI } \\
1.11,1.42 \text { ) }\end{array}$ \\
\hline $\begin{array}{l}\text { Silbert et al. } \\
2018\end{array}$ & $\begin{array}{l}\text { Narrative } \\
\text { review }\end{array}$ & International & $\mathrm{n} / \mathrm{a}$ & $\mathrm{n} / \mathrm{a}$ & $\begin{array}{l}\text { Food insecurity associated with increased } \\
\text { hypoglycemia risk }\end{array}$ \\
\hline $\begin{array}{l}\text { Tait et al. } \\
2018\end{array}$ & Longitudinal & Ontario, CA & 4,739 & $\begin{array}{l}\text { Median } \\
\text { of } \\
11.6 \\
\text { years }\end{array}$ & $\begin{array}{l}\text { Food insecurity associated with increased risk of } \\
\text { developing T2D (HR 2.40, 95\% CI 1.17, 4.94) }\end{array}$ \\
\hline $\begin{array}{l}\text { Berkowitz } \\
\text { et al. } 2018\end{array}$ & Longitudinal & Massachusetts & 391 & $\begin{array}{l}\text { Mean of } \\
37 \\
\text { mon- } \\
\text { ths }\end{array}$ & $\begin{array}{l}\text { Food insecurity associated with greater } \mathrm{HbA} 1 \mathrm{c} \\
\text { (difference of } 0.6 \text { percentage points, } 95 \% \text { CI } 0.4 \text {, } \\
0.8 \text { percentage points) }\end{array}$ \\
\hline $\begin{array}{l}\text { Shalowitz } \\
\text { et al. } 2017\end{array}$ & Longitudinal & $\begin{array}{l}\text { Multi-site federally qualified health } \\
\text { center in Midwestern USA }\end{array}$ & 336 & $\begin{array}{l}24 \\
\text { mon- } \\
\text { ths }\end{array}$ & $\begin{array}{l}\text { Food insecurity participants had higher hemoglobin } \\
\text { Alc at baseline and difference did not resolve over } \\
2 \text { years of follow-up }\end{array}$ \\
\hline $\begin{array}{l}\text { Schroeder } \\
\text { et al. } 2018\end{array}$ & Longitudinal & Colorado & 2,968 & $\begin{array}{l}12 \\
\text { mon- } \\
\text { ths }\end{array}$ & $\begin{array}{l}\text { Association between food insecurity and emergency } \\
\text { department visits and hospitalizations not } \\
\text { significant after adjustment }\end{array}$ \\
\hline $\begin{array}{l}\text { Blitstein } \\
\text { et al. } 2020\end{array}$ & $\begin{array}{l}\text { Interventional, } \\
\text { pre/post }\end{array}$ & $\begin{array}{l}\text { Federally qualified health centers, } \\
\text { Midwestern USA }\end{array}$ & 398 & $\begin{array}{l}\text { 6-9 } \\
\text { mon- } \\
\text { ths }\end{array}$ & $\begin{array}{l}\text { Intervention combining food insecurity screening, } \\
\text { nutritional education, and assistance with } \\
\text { accessing food resources associated with lower } \\
\text { hemoglobin Alc }(-0.22 \text { percentage points, } \mathrm{P}= \\
\text { 0.01) post-intervention }\end{array}$ \\
\hline $\begin{array}{l}\text { Berkowitz } \\
\text { et al. } 2019\end{array}$ & $\begin{array}{l}\text { Interventional, } \\
\text { crossover } \\
\text { RCT }\end{array}$ & Massachusetts & 42 & $\begin{array}{l}6 \\
\text { mon- } \\
\text { ths }\end{array}$ & $\begin{array}{l}\text { Healthy Eating Index diet quality score was } 71.3 \text { (SD } \\
7.5 \text { ) while receiving meals and } 39.9 \text { (SD } 7.8 \text { ) } \\
\text { when not receiving meals (difference } 31.4 \text { points, } \\
\mathrm{P}<0.0001 \text { ) }\end{array}$ \\
\hline $\begin{array}{l}\text { Ferrer et al. } \\
2019\end{array}$ & $\begin{array}{l}\text { Interventional, } \\
\text { RCT }\end{array}$ & $\begin{array}{l}\text { Primary care practice in San Antonio, } \\
\text { Texas }\end{array}$ & 43 & $\begin{array}{l}6 \\
\text { mon- } \\
\text { ths }\end{array}$ & $\begin{array}{l}\text { Hemoglobin A1c decreased } 3.1 \text { percentage points in } \\
\text { the intervention group vs. } 1.7 \text { percentage points in } \\
\text { the control group }(\mathrm{P}=.01)\end{array}$ \\
\hline $\begin{array}{l}\text { Seligman } \\
\text { et al. } 2018\end{array}$ & $\begin{array}{l}\text { Interventional, } \\
\text { RCT }\end{array}$ & $\begin{array}{l}\text { Food banks in Oakland, CA, Detroit, } \\
\text { MI, and Houston, TX }\end{array}$ & 568 & $\begin{array}{l}6 \\
\text { mon- } \\
\text { ths }\end{array}$ & $\begin{array}{l}\text { Intervention did not result in decreased hemoglobin } \\
\text { A1c (difference between intervention and control } \\
\text { group } 0.24 \text { percentage points; } 95 \% \text { CI }-0.09 \text {, } \\
0.58 \text { ) but did reduce food insecurity (risk ratio } \\
0.85 .95 \% \text { CI } 0.73,0.98 \text { ) and increase fruit and } \\
\text { vegetable consumption }\end{array}$ \\
\hline \multicolumn{6}{|c|}{ Coronary heart disease, congestive heart failure, and stroke } \\
\hline $\begin{array}{l}\text { Venci and } \\
\text { Lee } 2018\end{array}$ & Cross-sectional & $\begin{array}{l}\text { USA, nationally representative } \\
\text { survey }\end{array}$ & 30,010 & $\mathrm{n} / \mathrm{a}$ & $\begin{array}{l}\text { Very low food security was associated with greater } \\
\text { odds of having been diagnosed with coronary } \\
\text { heart disease (OR: } 1.75,95 \% \text { CI: } 1.37,2.24 \text { ) }\end{array}$ \\
\hline $\begin{array}{l}\text { Berkowitz } \\
\text { et al. } 2017\end{array}$ & Cross-sectional & $\begin{array}{l}\text { USA, nationally representative } \\
\text { survey }\end{array}$ & 21,196 & $\mathrm{n} / \mathrm{a}$ & $\begin{array}{l}\text { Food insecurity was more prevalent in individuals } \\
\text { with coronary heart disease }(20.5 \% \text { vs. } 11.9 \%, \mathrm{P} \\
<.001) \text { and congestive heart failure }(18.4 \% \text { vs. } \\
12.1 \%, \mathrm{P}=.004) \text {, compared with individual who } \\
\text { did not have the condition }\end{array}$ \\
\hline $\begin{array}{l}\text { Charkhchi } \\
\text { et al. } 2018\end{array}$ & Cross-sectional & $\begin{array}{l}\text { Representative sample of } 11 \text { US } \\
\text { states and } 1 \text { US territory }\end{array}$ & 84,353 & $\mathrm{n} / \mathrm{a}$ & $\begin{array}{l}\text { History of cardiovascular disease was associated } \\
\text { with a greater likelihood of food insecurity (OR } \\
1.75,95 \% \text { CI 1.12, 2.73) }\end{array}$ \\
\hline $\begin{array}{l}\text { Hummel } \\
\text { Scott et al. } \\
2018\end{array}$ & $\begin{array}{l}\text { Interventional, } \\
\text { RCT }\end{array}$ & Michigan and New York, USA & 66 & $\begin{array}{l}3 \text { mon- } \\
\text { ths }\end{array}$ & $\begin{array}{l}\text { Those who received the meals had greater increases } \\
\text { in quality of life than usual care participants } \\
\text { (Kansas City Cardiomyopathy Questionnaire } \\
\text { Clinical Summary Score increased from a mean of } \\
47 \text { to } 65 \text { in the intervention arm vs. } 45 \text { to } 55 \text { in the } \\
\text { control arm; } \mathrm{P}=0.053 \text { ) }\end{array}$ \\
\hline
\end{tabular}

Chronic kidney disease 
Table 1 (continued)

\begin{tabular}{|c|c|c|c|c|c|}
\hline Author, year & Study design & Setting & Sample size & $\begin{array}{l}\text { Follow- } \\
\text { up }\end{array}$ & Key findings \\
\hline $\begin{array}{l}\text { Leung et al. } \\
2020\end{array}$ & Cross-sectional & $\begin{array}{l}\text { USA, nationally representative } \\
\text { sample of older adults }\end{array}$ & 2,048 & $\mathrm{n} / \mathrm{a}$ & $\begin{array}{l}\text { Chronic kidney disease was more common in those } \\
\text { with food insecurity, compared with those who } \\
\text { were not }(5.6 \% \text { vs. } 2.0 \%, \mathrm{P}=.005)\end{array}$ \\
\hline $\begin{array}{l}\text { Banerjee } \\
\text { et al. } 2017\end{array}$ & Longitudinal & $\begin{array}{l}\text { USA, nationally representative } \\
\text { survey, adults with household } \\
\text { income } \leq 400 \% \text { of the federal } \\
\text { poverty level }\end{array}$ & 12,768 & $\begin{array}{r}\text { Median } \\
\text { of } 12 \\
\text { years }\end{array}$ & $\begin{array}{l}\text { Of those with CKD at baseline, those who reported } \\
\text { being food insecure were more likely to progress } \\
\text { to end-stage renal disease than those who were } \\
\text { food secure (relative hazard } 1.38,95 \% \text { CI } 1.08 \text {, } \\
3.10 \text { ) }\end{array}$ \\
\hline $\begin{array}{l}\text { Crews et al. } \\
2018\end{array}$ & $\begin{array}{r}\text { Narrative } \\
\text { review }\end{array}$ & International & $\mathrm{n} / \mathrm{a}$ & $\mathrm{n} / \mathrm{a}$ & $\begin{array}{l}\text { Food insecurity is more prevalent in areas with } \\
\text { greater CKD prevalence }\end{array}$ \\
\hline
\end{tabular}

$R C T$, randomized clinical trial; $C K D$, chronic kidney disease; $E S R D$, end-stage renal disease; $T 2 D$, type 2 diabetes

association varied significantly by gender such that risk was greater for women than men [13]. A similar study among 828 low-income immigrants in Boston, MA, showed that, in adjusted models, participants reporting food hardship were $17 \%$ more likely to be obese than those who did not report food hardship (RR 1.17, 95\% CI 1.07, 1.29) [14]. A study using nationally representative NHANES (National Health and Nutrition Examination Survey) data also found greater odds of obesity among women who reported food insecurity (OR $1.41 ; 95 \%$ CI 1.22, 1.62 ) [15]. Food insecurity among college students has become an active topic of investigation. A study analyzing obesity in 683 second year students from eight US universities found food-insecure students had a significantly higher BMI than food-secure students $(26.0 \mathrm{~kg} / \mathrm{m} \mathrm{[2]} \pm 0.4$ compared with $24.2 \mathrm{~kg} / \mathrm{m}$ [2] $\pm 0.1, \mathrm{P}=0.001$ ) [16]. Food insecurity was significantly associated with obesity in both men (OR 3.84; 95\% Cl: 1.47, 10.02) and women (OR 2.88, $95 \% \mathrm{Cl}: 1.46,5.71)$ after adjusting for demographic characteristics. In contrast to these studies, however, a crosssectional study of Danish participants did not find an association between food insecurity and obesity after demographic adjustment [17]. Furthermore, a study of 14,786 young adult participants did not find that food insecurity was associated with obesity after demographic adjustment (OR 1.12, 95\% Cl $0.97,1.29)$ [18].

In addition to the above studies, Moradi et al. conducted an important meta-analysis examining the association between food insecurity and overweight/obesity [19•]. Using data from 115,993 individuals across 18 studies in 14 countries, they found that food insecurity was associated with obesity overall (OR 1.15, 95\% CI 1.06, 1.23). Furthermore, this study found that within food-insecure households, women had greater prevalence of obesity than men (OR 1.26, 95\% CI 1.05, 1.46). Another important study from Keenan et al. used structural equation modeling to examine mechanisms between food insecurity and obesity in a study of 604 adults from the UK $[20 \bullet \cdot$. They found that food insecurity was, as expected, associated with poor diet quality and higher BMI. The relationship between food insecurity and higher BMI, after adjusting for income, was mediated by the psychological experience of food insecurity, in particular greater distress and eating to cope with this distress.

\section{Hypertension}

The recent literature is consistent with greater hypertension risk among those who are food insecure, compared with those who are not. A cross-sectional study from Helmick et al. found that after adjusting for covariates, food insecurity was associated with greater odds of hypertension $(\mathrm{OR}=1.77, \mathrm{P}=$ 0.001 ) [21]. A nationally representative study using data from the National Longitudinal Study of Adolescent to Adult Health concluded that food-insecure young adults (aged 24 32 ) had greater odds of hypertension $(1.40,95 \%$ CI 1.14 1.72) compared with food-secure young adults [18]. Another nationally representative, cross-sectional study using data from NHANES also revealed that age-standardized rates of food insecurity were greater in participants with hypertension (14.1\% vs. $11.1 \%, \mathrm{P}=0.0003$ ) [22]. We found one study, based on data from the National Poll on Healthy Aging, that did not find significantly greater hypertension prevalence when comparing food-insecure with food-secure older adults (aged 50-80 years) (40.3\% hypertension among food-secure adults vs. $46.7 \%$ among food-insecure adults, $\mathrm{P}=0.10$ ) [23]. However, this study did not report adjusted results for this comparison, so the lack of difference may be explained by confounding, or possibly by overall high prevalence of hypertension in this age group.

A systematic review by da Silva Miguel et al. that evaluated the association between food insecurity and cardiometabolic risk factors concluded that there was a direct association between food insecurity and hypertension after adjusting for sociodemographic, economic, and lifestyle characteristics 
[24]. We did not identify longitudinal or interventional studies regarding food insecurity and hypertension.

\section{Diabetes}

The recent literature suggests that food-insecure individuals are significantly more likely to have pre-diabetes and diabetes, worse control of glycemia and cardiovascular risk factors, and more diabetes complications than those who are food secure, even after adjustment for sociodemographic, economic, and lifestyle factors. A cross-sectional study that examined NHANES data for 3684 younger adults (age 20-39 years) found a high prevalence of prediabetes/diabetes (37.4\%), and significantly greater odds of prediabetes/diabetes after adjustment for age, sex, and income (OR 1.36, 95\% CI:1.00, 1.85) [25]. An important study by Walker et al. used structural equation modeling to investigate the relationship between food insecurity and hemoglobin Alc in individuals with type 2 diabetes. They found that food insecurity was associated with both a direct pathway to increased hemoglobin A1c ( $\mathrm{r}$ $=0.66, \mathrm{P}=0.03)$, and an indirect pathway through increased stress $(r=0.14, P<0.001)[26 \bullet$ ]. A study that examined sex and race/ethnicity differences in the association between food insecurity and prediabetes using nationally representative National Health Interview Survey data concluded that food insecurity was associated with pre-diabetes in women, using models adjusted for demographic and socioeconomic characteristics (OR 1.62, 95\% CI 1.22, 2.16). Examining particular racial/ethnic groups, non-Hispanic white women (OR 1.53 $95 \%$ CI 1.04, 2.53) and non-Hispanic black women (OR $2.3095 \%$ CI 1.44, 3.66) had significantly increased risk. The magnitude of the odds ratio was similar for Hispanic women (OR 1.43, 95\% CI 0.74, 2.76), though not statistically significant, and no association was seen in men [27]. A study using NHANES data in older adults found that, among those who were food insecure, men had lower odds of diabetes in comparison to women (OR: $0.39,95 \%$ CI $0.23,0.66)$ [28]. Finally, a meta-analysis of cross-sectional studies found that household food insecurity was significantly associated with odds of type 2 diabetes (OR 1.27, 95\% CI 1.11, 1.42) [29]. With regard to diabetes complications, a 2019 review concluded that food insecurity is associated with increased hypoglycemia risk [30].

Longitudinal studies have supported similar conclusions. An important study from Tait et al. used data from the Canadian Community Health Survey linked to an administrative database to examine incident diabetes over a median follow-up of 11.6 years. They found that Canadians in foodinsecure households had more than two times the risk of developing type 2 diabetes compared to those in food-secure households ( $\mathrm{HR}=2.40,95 \% \mathrm{CI}=1.17,4.94)$, and that greater BMI may explain some of this association [31•]. A study that examined the longitudinal relationship between food insecurity and diabetes control that followed 391 diabetes patients for a mean of 37 months found that food insecurity was associated with higher $\mathrm{HbAlc}$ (difference of 0.6 percentage points, 95\% CI 0.4, 0.8 percentage points) [32]. A similar study that examined diabetes control in a cohort of 336 primary care patients over 24 months found that those with food insecurity had higher hemoglobin A1c at baseline, and that this difference did not resolve over 2 years of follow-up [33]. A study among older individuals with diabetes found that those who reported food insecurity were more likely to have an emergency department visit $(\mathrm{OR}=1.4,95 \%$ CI 1.15 , 1.72 ) or hospitalization $(\mathrm{OR}=1.41,95 \% \mathrm{CI} 1.11,1.78)$ in the year following the food security assessment [34], but this association was no longer significant after adjustment. However, this study used a non-validated assessment of food insecurity that is likely to result in misclassification, which may have biased results to the null.

Food insecurity has recently become a more common target of diabetes interventions. A pre/post study that examined an intervention combining food insecurity screening, nutritional education, and assistance with accessing food resources federally qualified health center network found a decrease in hemoglobin Alc $(-0.22$ percentage points, $\mathrm{P}=0.01)$ [35], although results may have been affected by high loss to follow-up. A pilot study of a medically tailored meal intervention found improved diet quality among individuals with type 2 diabetes and food insecurity [36]. Furthermore, a small randomized trial ( $n=43$ at follow-up) found a large decrease in hemoglobin Alc (1.4 percentage points, $\mathrm{P}=.01)$ with a collaborative primary care and food bank intervention [37]. However, a larger randomized trial $(n=568)$ of a combined food provision and diabetes self-management education intervention based at food pantries did not find a decrease in hemoglobin Alc (difference between intervention and control group 0.24 percentage points; $95 \% \mathrm{CI}-0.09,0.58)$, though it did find a reduction in food insecurity (risk ratio $0.85 .95 \%$ CI $0.73,0.98)$ and improvement in fruit and vegetable consumption $[38 \bullet \bullet]$.

\section{Coronary Heart Disease, Congestive Heart Failure, and Stroke}

In general, current literature supports an association between food insecurity and coronary heart disease, congestive heart failure, and stroke. Recent cross-sectional studies indicate that such cardiovascular disease risk could be magnified by food insecurity. A study using National Health Interview Survey data for 30,010 adults found that very low food security was associated with greater odds of having been diagnosed with coronary heart disease, even after adjustment for potential sociodemographic confounding factors (OR: 1.75, 95\% CI: $1.37,2.24)[39]$. Low food security was similarly associated with greater risk for having been diagnosed with a stroke (OR $1.51,95 \%$ CI 1.12, 2.04). Another study that used NHANES 
data to examine age-standardized food insecurity prevalence from 2005 to 2012 found that food insecurity was more prevalent in individuals with coronary heart disease $(20.5 \%$ vs. $11.9 \%, \mathrm{P}<.001)$ and congestive heart failure $(18.4 \%$ vs. $12.1 \%, \mathrm{P}=.004)$ when compared to unaffected individuals [22]. A study using data from the 2015 Behavioral Risk Factor Surveillance System examined whether a history of cardiovascular disease was associated with a greater likelihood of food insecurity, and found that it was (OR 1.75, 95\% CI 1.12, 2.73). This study, however, did not find a statistically significant association between a history of stroke and food insecurity, though the point estimate did suggest higher risk and the smaller sample size may have meant this analysis was underpowered (OR 1.25, 95\% CI 0.75, 2.09) [40].

We did not find any interventional studies that addressed food insecurity in order to improve health outcomes for individuals with coronary heart disease, congestive heart failure, or stroke. However, one study that is worth noting is a randomized clinical trial $(n=66)$ from Hummel et al. [41•]. The intervention arm in this study provided 4 weeks of healthy home-delivered meals for patients discharged after a heart failure hospitalization (though it did not assess food security status), and found that those who received the meals had greater increases in quality of life than usual care participants (Kansas City Cardiomyopathy Questionnaire Clinical Summary Score increased from a mean of 47 to 65 in the intervention arm vs. 45 to 55 in the control arm; $\mathrm{P}=0.053)$. Thirty-day heart failure rehospitalizations (11\% vs. $27 \%$; $\mathrm{P}=$ $0.06)$ and days hospitalized ( 17 vs. $55 ; \mathrm{P}=0.055)$ were estimated to be lower in meal participants as well. These differences were not statistically significant at the alpha $<0.05$ level, but this smaller trial represents promising preliminary data that supports further investigation of using medically tailored meal interventions after heart failure discharge.

\section{Chronic Kidney Disease}

The relationship between chronic kidney disease and food insecurity is relatively understudied compared to some other conditions. Nevertheless, recent literature suggests an association between CKD and food insecurity. A cross-sectional study looking at a nationally representative sample of older US adults found that chronic kidney disease was more common in those with food insecurity, compared with those who were not experiencing food insecurity (5.6\% vs. $2.0 \%, \mathrm{P}=$ .005) [23]. An important longitudinal study from Banerjee et al. examined 2,320 adults with CKD in the NHANES III study [42•]. Of this group, those who reported being food insecure at baseline were more likely to progress to endstage renal disease than those who were food secure (relative hazard $1.38,95 \%$ CI 1.08, 3.10), after adjustment for demographics, income, diabetes, hypertension, estimated glomerular filtration rate, and albuminuria, and accounting for competing risks. Finally, a review article that examined CKD "hotspots" (areas with high prevalence of CKD) found that food insecurity is common in such locations [43]. We did not find any studies that address food insecurity as part of interventions for individuals with chronic kidney disease.

\section{Pediatric Populations (Table 2)}

\section{Overweight/Obesity}

In $2018,19.3 \%$ of US children and adolescents (2-19 years) were obese and another $16.1 \%$ were overweight [44]. In contrast to the literature in adults in which the association between food insecurity and overweight/obesity is clear, our review suggests the relationship in children is more complicated. Specifically, there is heterogeneity across studies such that some find a statistically significant association between food insecurity and greater overweight/obesity prevalence, or other indicators of adiposity, while many others do not. The heterogeneity of these findings is likely related to study design (cross-sectional vs. longitudinal), sample size, representativeness of the sample, and the timeframe over which overweight/ obesity may develop in relation to food insecurity. An NHANES study of children 9-17 years of age did not find an association between household food insecurity and BMI zscore [45]. Furthermore, an analysis of participants in a randomized clinical did not show an association between food insecurity and weight [46]. Similarly, a cross-sectional study using a clinic-based sample in Boston did not find an association between food insecurity and weight classification [47]. Three cross-sectional studies provided more support for a relationship between food insecurity and overweight/obesity (or increased adiposity), but even here the evidence was not clear cut. A cross-sectional, clinic-based sample in Philadelphia found an association between food insecurity and BMI zscore of borderline statistical significance $(0.3$ higher, $95 \%$ CI $0.0,0.6, \mathrm{P}=0.051$ ), and with significantly greater waist circumference z-score and percent body fat z-score, both of which suggest greater adiposity [48]. A cross-sectional study using data from Children's HealthWatch found among 28,184 children $<4$ years of age, household food insecurity was associated with increased odds of obesity among children 25 to 36 months old, but not among children 0-12, 13-24, and 3748 months [49]. A cross-sectional study of 822 children who were obese found that food insecurity was associated with higher BMI percentile $(\mathrm{P}<.0001)$ [50].

Longitudinal studies examining the relationship between food insecurity status and pediatric overweight/obesity were similarly mixed. Findings from the Early Childhood Longitudinal Study-Kindergarten (ECLS-K) Cohort 19982007 found children who experienced food insecurity had a relative risk of 1.27 (95\% CI 1.07-1.51), 1.21 (95\% CI 1.08$1.35)$, and 1.28 (95\% CI 1.07-1.53) of overweight/obesity in 
Table 2 Selected characteristics of included studies of children

\begin{tabular}{|c|c|c|c|c|c|}
\hline $\begin{array}{l}\text { Author, } \\
\text { year }\end{array}$ & Study design & Setting & $\begin{array}{l}\text { Sample } \\
\text { size }\end{array}$ & $\begin{array}{l}\text { Follow- } \\
\text { up }\end{array}$ & Key findings \\
\hline \multicolumn{6}{|c|}{ Overweight/obesity } \\
\hline $\begin{array}{l}\text { Nguyen } \\
\text { et al. } \\
2017\end{array}$ & Cross-sectional & $\begin{array}{l}\text { USA, nationally representative } \\
\text { survey }\end{array}$ & 4,719 & $\mathrm{n} / \mathrm{a}$ & $\begin{array}{l}\text { There was no significant overall relationship between } \\
\text { household food security and BMI percentile }(0.00 \text { change in } \\
\text { percentile per } 1 \text { point change in food security [ } 95 \% \text { CI } \\
-0.98,0.98])\end{array}$ \\
\hline $\begin{array}{l}\text { Orr et al. } \\
2020\end{array}$ & Cross-sectional & $\begin{array}{l}\text { 2-year-old children participating in } \\
\text { randomized controlled trial }\end{array}$ & 477 & $\mathrm{n} / \mathrm{a}$ & $\begin{array}{l}\text { There were no differences in child weight status as assessed by } \\
\text { mean BMI z-scores or proportion of children who were } \\
\text { overweight or obese, or prevalence of parent } \\
\text { overweight/obesity, between food secure and food insecure } \\
\text { households }\end{array}$ \\
\hline $\begin{array}{l}\text { Baer et al. } \\
2018\end{array}$ & Cross-sectional & Urban center in northeastern USA & 376 & $\mathrm{n} / \mathrm{a}$ & $\begin{array}{l}\text { There were no significant associations between food security } \\
\text { level and weight classification }\end{array}$ \\
\hline $\begin{array}{l}\text { Poulsen } \\
\text { et al. } \\
2019\end{array}$ & Cross-sectional & Pennsylvania, USA & 434 & $\mathrm{n} / \mathrm{a}$ & $\begin{array}{l}\text { Youth from food-insecure households had higher mean } \\
\text { Z-scores for (beta [standard error]) BMI (.30 [.15]), waist } \\
\text { circumference (.27 [.12]), and percent body fat (.43 [.16]) }\end{array}$ \\
\hline $\begin{array}{l}\text { Drennen } \\
\text { et al. } \\
2019\end{array}$ & Cross-sectional & $\begin{array}{l}\text { Caregivers of young children at } \\
\text { medical centers in } 5 \text { US cities }\end{array}$ & 28,184 & $\mathrm{n} / \mathrm{a}$ & $\begin{array}{l}\text { Except at } 25 \text { to } 36 \text { months, neither household nor child food } \\
\text { insecurity were associated with obesity, underweight, or } \\
\text { stunting }\end{array}$ \\
\hline $\begin{array}{l}\text { Oberle } \\
\text { et al. } \\
2019\end{array}$ & Cross-sectional & $\begin{array}{l}\text { Pediatric patients with obesity (BMI } \\
\geq 95 \text { th percentile) seen at a weight } \\
\text { management clinic }\end{array}$ & 822 & $\mathrm{n} / \mathrm{a}$ & $\begin{array}{l}\text { FI households had significantly higher BMI relative to the } \\
\text { 95th percentile, compared with those from food secure } \\
\text { households }(147.9 \% \text { above } 95 \text { th percentile } \pm 34.3 \% \text { vs. } \\
132.2 \% \pm 23.6 \% ; \mathrm{P}=0.000) \text {. }\end{array}$ \\
\hline $\begin{array}{l}\text { Zhu et al. } \\
2020\end{array}$ & Longitudinal & $\begin{array}{l}\text { Kindergarteners through } 8 \text { th graders } \\
\text { in the USA }\end{array}$ & 6,368 & $\stackrel{\sim 8}{\text { years }}$ & $\begin{array}{l}\text { Children with food insecurity had a higher body mass index } \\
\text { Z-score than the food-secure children in the 3rd, 5th, and 8th } \\
\text { grades, respectively }\end{array}$ \\
\hline $\begin{array}{l}\text { Lee et al. } \\
2018\end{array}$ & Longitudinal & $\begin{array}{l}\text { US nationally representative sample } \\
\text { of children in kindergarten in } 2010\end{array}$ & 8,167 & $\begin{array}{l}\sim 3 \\
\text { years }\end{array}$ & $\begin{array}{l}\text { First-grade food insecurity was significantly correlated with } \\
\text { increased BMI z-score in first through third grades; for } \\
\text { example, at first grade, with food insecurity } 0.6 \text { ( } 95 \% \mathrm{CI} \text {, } \\
0.5,0.7 \text { ) vs. food secure } 0.4 \text { ( } 95 \% \mathrm{CI}, 0.4,0.5) \text {. }\end{array}$ \\
\hline $\begin{array}{l}\text { Lohman } \\
\text { et al. } \\
2018\end{array}$ & Longitudinal & Midwestern USA & 559 & $\begin{array}{l}\sim 16 \\
\text { years }\end{array}$ & $\begin{array}{l}\text { Higher levels of food insecurity at age } 15 \text { years led to a more } \\
\text { rapid increase in BMI }\end{array}$ \\
\hline \multicolumn{6}{|c|}{ Hypertension } \\
\hline $\begin{array}{l}\text { South } \\
\text { et al. } \\
2019\end{array}$ & Cross-sectional & $\begin{array}{l}\text { USA, nationally representative } \\
\text { survey }\end{array}$ & 7,125 & $\mathrm{n} / \mathrm{a}$ & $\begin{array}{l}\text { Household food insecurity and child food insecurity associated } \\
\text { with elevated blood pressure in adjusted models (OR 1.26, } \\
95 \% \text { CI 1.04, 1.54; OR 1.42, 95\% CI 1.03, 1.96, respectively) }\end{array}$ \\
\hline $\begin{array}{l}\text { Lee et al. } \\
2019\end{array}$ & Cross-sectional & $\begin{array}{l}\text { USA, nationally representative } \\
\text { survey }\end{array}$ & 2,662 & $\mathrm{n} / \mathrm{a}$ & $\begin{array}{l}\text { Food insecurity associated with elevated blood pressure } \\
\text { among children } 12 \text { to } 17 \text { years of age in adjusted models } \\
\text { (OR } 1.65,95 \% \text { CI } 1.38,1.98 \text { ) }\end{array}$ \\
\hline \multicolumn{6}{|c|}{ Diabetes mellitus and pre-diabetes } \\
\hline $\begin{array}{l}\text { Lee et al. } \\
2019\end{array}$ & Cross-sectional & $\begin{array}{l}\text { USA, nationally representative } \\
\text { survey }\end{array}$ & 2,662 & $\mathrm{n} / \mathrm{a}$ & $\begin{array}{l}\text { Food insecurity associated with increased odds of prediabetes } \\
\text { in adjusted models (OR 1.96, 95\% CI 1.17, 3.19) in } \\
\text { adolescents age } 12-19 \text { years }\end{array}$ \\
\hline $\begin{array}{l}\text { Thomas } \\
\text { et al. } \\
2019\end{array}$ & Cross-sectional & $\begin{array}{l}\text { USA, nationally representative } \\
\text { survey }\end{array}$ & 29,341 & $\mathrm{n} / \mathrm{a}$ & $\begin{array}{l}\text { Food insecurity was not associated with parental-reported } \\
\text { diagnosis of diabetes in children } 2-17 \text { (estimated difference } \\
\text { in prevalence of diabetes between food-insecure and } \\
\text { food-secure households } 0.000(95 \% \text { CI }-0.002,0.001)\end{array}$ \\
\hline $\begin{array}{l}\text { Clemens } \\
\text { et al. } \\
2020\end{array}$ & Longitudinal & Ontario, Canada & 34,042 & $\begin{array}{l}\sim 9.5 \\
\quad \text { years }\end{array}$ & $\begin{array}{l}\text { Food insecurity associated with a point estimate for increased } \\
\text { risk of incident diabetes that was not statistically significant } \\
\text { in adjusted models (HR } 1.30,95 \% \text { CI } 0.72,2.37 \text { ) }\end{array}$ \\
\hline $\begin{array}{l}\text { Mendoza } \\
\text { et al. } \\
2018\end{array}$ & Cross-sectional & $\begin{array}{l}\text { Washington and South Carolina, } \\
\text { USA }\end{array}$ & 226 & $\mathrm{n} / \mathrm{a}$ & $\begin{array}{l}\text { Youth and young adults with type } 1 \text { diabetes from } \\
\text { food-insecure households at greater risk of poor glycemic } \\
\text { control (OR } 2.37,95 \% \text { CI } 1.10,5.09 \text { ) and emergency } \\
\text { department visits (prevalence ratio } 2.95,95 \% \text { CI } 1.17,7.45 \text { ) }\end{array}$ \\
\hline
\end{tabular}

$B M I$, body mass index 
the $3 \mathrm{rd}, 5$ th, and 8 th grade respectively [51]. However, a studying using data from the ECLS-K Cohort 2011 found that food insecurity during kindergarten was not associated with BMI z-score during kindergarten or the 3rd grade, but food insecurity during the first grade was associated with increased BMI z-score $(\mathrm{P}<0.005)$ in the first grade and increased BMI $\mathrm{z}$-score in the 3rd grade $(\mathrm{P}<0.05)$ [52]. A study among children, primarily in the Midwest, who experienced an economic shock, found that exposure to food insecurity at age 15 was predicted to be associated with more rapid increase in BMI from age 16 to $31(\mathrm{P}<.01)$ [53].

\section{Hypertension}

In a cross-sectional study of NHANES data that examined children 8 to 17 years of age, household food insecurity and child food insecurity were associated with elevated blood pressure in adjusted models (OR 1.26, 95\% CI 1.04,1.54; OR 1.42, 95\% CI 1.03, 1.96, respectively) [54]. These results are consistent with another cross-sectional NHANES analysis that found food insecurity to be associated with elevated blood pressure among children 12 to 17 years of age in adjusted models $(\mathrm{OR}=1.65,95 \%$ CI: $1.38,1.98)[55]$.

\section{Diabetes and Pre-Diabetes}

Recent literature in children also suggests a more nuanced relationship between food insecurity and diabetes and/or prediabetes than in adults. Key to interpreting these findings is the long-time horizon over which type 2 diabetes develops. For example, a cross-sectional NHANES analysis of 2662 adolescents aged 12 to 19 found food insecurity was associated with increased odds of prediabetes/diabetes in adjusted models (OR: 1.96, 95\% CI: 1.17, 3.19), along with greater hemoglobin A1c (5.21\% vs. 5.16\%, $\mathrm{P}=0.03)$ [55]. However, a cross-sectional study of 29,341 children aged 2 to 17 years found no association between food insecurity and parental-reported child diagnosis of diabetes [56]. In this study, the authors note that the gradual development of diabetes is one explanation for why a significant association may not have been observed. Furthermore, an important longitudinal study that followed 34,042 children $<18$ years of age in Ontario, Canada, for a median of 9.5 years found, in adjusted proportional hazard models, that food insecurity was associated with a point estimate for increased risk of incident diabetes that was not statistically significant (HR $1.30,95 \%$ CI $0.72,2.37)$ [57]. The authors note that with aging of the cohort and longer follow-up, a significant association may emerge. A key consideration is that food insecurity experienced in childhood may be associated with developing diabetes later in life, even if food insecurity is not clearly associated with development of diabetes during childhood. It is also important to note that, given the mechanisms discussed in the Introduction, food insecurity is more likely to be related to type 2 , rather than type 1 diabetes.

With regard to glycemic control in those with diabetes, a cross-sectional analysis using data from the Washington and South Carolina SEARCH for Diabetes in Youth Study sites found that youth and young adults from food-insecure households had, in adjusted models, greater risk of poor glycemic control (OR 2.37, 95\% CI: 1.10,5.09) relative to their peers from food-secure households [58 ${ }^{\bullet}$. Participants in food-insecure, compared with food-secure, households were also more likely to have an emergency department visits (prevalence ratio $2.95,95 \%$ CI $1.17,7.45$ ).

\section{Conclusions}

In this review of the association between food insecurity and cardiometabolic conditions, we found evidence for an overall association between food insecurity and increased risk across a number of specific conditions in adults. These include overweight/obesity, hypertension, diabetes, coronary heart disease, congestive heart failure, stroke, and chronic kidney disease. In pediatric populations, the evidence was more mixed, though it should be noted that many cardiometabolic conditions develop slowly, meaning that observable conditions in children are likely only the tip of the iceberg when considering how food insecurity may affect health across the life course. This is an area where additional research is needed. Specifically, life course epidemiology studies may be especially valuable. Three ways that food insecurity experienced during childhood may affect health even if overt clinical cardiometabolic conditions do not develop in childhood are exposures during critical developmental periods, setting health trajectories, and through cumulative exposure.

Our review is also notable for studies we did not find, which suggest both limitations of the current research and directions for future research. With some key exceptions, many studies were cross-sectional, which makes it impossible to untangle the specific relationship between food insecurity and the condition studied. While several studies did use nationally representative data with adequate samples, others used convenience samples and small sample sizes for the examined hypotheses. Two main approaches in study design will likely be helpful going forward. First, adequately powered longitudinal studies, with repeated and detailed assessment of food insecurity, sociodemographic and socioeconomic status indicators, other health-related social needs (such as housing and transportation), and incident cardiometabolic outcomes, would be important additions to epidemiologic literature on this topic. Second, adequately powered interventional studies, using comparison groups and either randomized or 
strong quasi-experimental designs, would enhance not only our understanding of the relationship between food insecurity and cardiometabolic disease, but, more importantly, our ability to address food insecurity for those who are experiencing its ill-effects. These studies should assess a broad range of outcomes, and include qualitative evaluation to understand contextual factors that influence intervention results.

Given the association between food insecurity and poor health, food insecurity interventions will likely fall into two main, complementary, categories. The first are programs that combine food insecurity intervention with clinical management to improve specific clinical outcomes. For example, medically tailored meal programs for individuals with food insecurity and diabetes can combine aspects of food insecurity amelioration, lifestyle intervention, and diabetes selfmanagement education to improve glycemic control. These types of interventions will likely be closely connected to clinical settings, and may also involve community organizations with a focus on serving individuals experiencing food insecurity.

The second category of food insecurity interventions are policies and programs. SNAP (the Supplemental Nutrition Assistance Program) is the United States' largest effort to combat food insecurity. It has been shown to reduce both the depth and breadth of food insecurity, and has been associated with important health benefits [59-61]. Furthermore, the Special Supplemental Nutrition Program for Women, Infants, and Children (WIC), and the National School Lunch/School Breakfast program are also largescale food insecurity interventions with important benefits in their own right $[62,63]$. Recently, the Pandemic Electronic Benefits Transfer (P-EBT) program has brought the benefits of school feeding programs to families affected by the COVID-19 pandemic [64]. Despite the success of these programs, it is worth considering how they might be improved. Benefit levels are likely too low [65], and eligibility is unnecessarily restrictive. Moving away from means-tested programs designed with an ethos of "poorrelief" and towards universal programs meant to ensure access to needed nutrition for all is a promising approach [66]. It is also worth reconsidering aspects of the political economy that result both in high levels of food insecurity observed in the USA, and its very unequal distributionspecifically that individuals who identify as Black, Hispanic, or Indigenous are disproportionately affected, as are women [67].

In recent years, our understanding of food insecurity as an important risk factor for cardiometabolic conditions has greatly improved. Yet there remain many unanswered questions in this field, ones that require dedicated and rigorous research to answer. Perhaps more important, however, is what we do with this knowledge. Interventions that reduce food insecurity and improve the health of those who experience it are an important part of improving health equity.

Funding Seth A. Berkowitz is funded, in part, by a grant from the National Institute of Diabetes and Digestive and Kidney Diseases (grant \#K23DK 109200), and has received compensation from the Aspen Institute for service as a consultant.

\section{Declarations}

Conflict in Interest Jennifer Te Vazquez declares that she has no conflict of interest.

Shi Nan Feng declares that she has no conflict of interest.

Colin J. Orr declares that he has no conflict of interest.

\section{References}

Papers of particular interest, published recently, have been highlighted as:

- Of importance

•. Of major importance

1. USDA ERS - Measurement. Accessed February 27, 2021. https:// www.ers.usda.gov/topics/food-nutrition-assistance/food-securityin-the-us/measurement/

2. USDA ERS - Key Statistics \& Graphics. Accessed February 27, 2021. https://www.ers.usda.gov/topics/food-nutrition-assistance/ food-security-in-the-us/key-statistics-graphics/

3. Orr CJ, Keyserling TC, Ammerman AS, Berkowitz SA. Diet quality trends among adults with diabetes by socioeconomic status in the U.S.: 1999-2014. BMC Endocr Disord. 2019;19(1):54. https:// doi.org/10.1186/s12902-019-0382-3.

4. Mello JA, Gans KM, Risica PM, Kirtania U, Strolla LO, Fournier L. How is food insecurity associated with dietary behaviors? An analysis with low income, ethnically diverse participants in a nutrition intervention study. J Am Diet Assoc. 2010;110(12):1906-11. https://doi.org/10.1016/j.jada.2010.09.011.

5. Weigel MM, Armijos RX. Food insecurity, cardiometabolic health, and health care in U.S.-Mexico border immigrant adults: an exploratory study. J Immigr Minor Health. 2019;21(5):1085-94. https:// doi.org/10.1007/s10903-018-0817-3.

6. Berkowitz SA, Seligman HK, Choudhry NK. Treat or eat: food insecurity, cost-related medication underuse, and unmet needs. Am J Med. 2014;127(4):303-310.e3. https://doi.org/10.1016/j. amjmed.2014.01.002.

7. Wilder ME, Kulie P, Jensen C, et al. The impact of social determinants of health on medication adherence: a systematic review and meta-analysis. J Gen Intern Med. 2021;29:1359-70. https://doi.org/ 10.1007/s11606-020-06447-0.

8. Silverman J, Krieger J, Kiefer M, Hebert P, Robinson J, Nelson K. The relationship between food insecurity and depression, diabetes distress and medication adherence among low-income patients with poorly-controlled diabetes. J Gen Intern Med. 2015;30(10):147680. https://doi.org/10.1007/s11606-015-3351-1.

9. Arenas DJ, Thomas A, Wang J, DeLisser HM. A systematic review and meta-analysis of depression, anxiety, and sleep disorders in US adults with food insecurity. J Gen Intern Med. 2019;34(12):2874 82. https://doi.org/10.1007/s11606-019-05202-4. 
10. Cardiovascular diseases (CVDs). Accessed February 27, 2021. https://www.who.int/news-room/fact-sheets/detail/cardiovasculardiseases-(cvds)

11. CDC. Heart Disease Facts | cdc.gov. Centers for Disease Control and Prevention. Published September 8, 2020. Accessed February 27, 2021. https://www.cdc.gov/heartdisease/facts.htm

12. van der Velde LA, Nyns CJ, Engel MD, Neter JE, van der Meer IM, Numans ME, et al. Exploring food insecurity and obesity in Dutch disadvantaged neighborhoods: a cross-sectional mediation analysis. BMC Public Health. 2020;20(1):569. https://doi.org/10.1186/ s12889-020-08611-x.

13. Castañeda J, Caire-Juvera G, Sandoval S, Castañeda PA, Contreras AD, Portillo GE, et al. Food security and obesity among Mexican agricultural migrant workers. Int J Environ Res Public Health. 2019;16(21):4171. https://doi.org/10.3390/ijerph16214171.

14. Caspi CE, Tucker-Seeley RD, Adamkiewicz G, Roberto CA, Stoddard AM, Sorensen GC. Food hardship and obesity in a sample of low-income immigrants. J Immigr Minor Health. 2017;19(1): 130-7. https://doi.org/10.1007/s10903-016-0344-z.

15. Ashe KM, Lapane KL. Food insecurity and obesity: exploring the role of social support. J Women's Health (Larchmt). 2018;27(5): 651-8. https://doi.org/10.1089/jwh.2017.6454.

16. El Zein A, Colby SE, Zhou W, et al. Food insecurity is associated with increased risk of obesity in US college students. Curr Dev Nutr. 2020;4(8):nzaa120. https://doi.org/10.1093/cdn/nzaa120.

17. Lund TB, Holm L, Tetens I, Smed S, Nielsen AL. Food insecurity in Denmark-socio-demographic determinants and associations with eating- and health-related variables. Eur J Pub Health. 2018;28(2): 283-8. https://doi.org/10.1093/eurpub/ckx121.

18. Nagata JM, Palar K, Gooding HC, Garber AK, Bibbins-Domingo $\mathrm{K}$, Weiser SD. Food insecurity and chronic disease in US young adults: findings from the National Longitudinal Study of Adolescent to Adult Health. J Gen Intern Med. 2019;34(12): 2756-62. https://doi.org/10.1007/s11606-019-05317-8.

19. Moradi S, Mirzababaei A, Dadfarma A, et al. Food insecurity and adult weight abnormality risk: a systematic review and meta-analysis. Eur J Nutr. 2019;58(1):45-61. https://doi.org/10.1007/s00394018-1819-6 Meta-analysis of studies examining food insecurity and risk for overweight/obesity.

20.• Keenan GS, Christiansen P, Hardman CA. Household food insecurity, diet quality, and obesity: an explanatory model. Obesity (Silver Spring). 2021;29(1):143-9. https://doi.org/10.1002/oby. 23033 Important study testing several hypothesized pathways between food insecurity and obesity using structural equation modeling.

21. Helmick M, Smith TM, Parks CA, Hill JL. Food insecurity increases odds of diabetes and hypertension, not obesity in medically underserved region. J Hunger Environ Nutr. 2020;15(1):128-39. https://doi.org/10.1080/19320248.2018.1538921.

22. Berkowitz SA, Berkowitz TSZ, Meigs JB, Wexler DJ. Trends in food insecurity for adults with cardiometabolic disease in the United States: 2005-2012. PLoS One. 2017;12(6):e0179172. https://doi.org/10.1371/journal.pone.0179172.

23. Leung CW, Kullgren JT, Malani PN, Singer DC, Kirch M, Solway E, et al. Food insecurity is associated with multiple chronic conditions and physical health status among older US adults. Prev Med Rep. 2020;20:101211. https://doi.org/10.1016/j.pmedr.2020. 101211.

24. Miguel EDS, Lopes SO, Araújo SP, Priore SE, Alfenas RCG, Hermsdorff HHM. Association between food insecurity and cardiometabolic risk in adults and the elderly: a systematic review. J Glob Health. 2020;10(2):020402. https://doi.org/10.7189/jogh.10. 020402.

25. Lee AM, Scharf RJ, DeBoer MD. Food insecurity is associated with prediabetes and dietary differences in U.S. adults aged 20-39. Prev
Med. 2018;116:180-5. https://doi.org/10.1016/j.ypmed.2018.09. 012 .

26.• Walker RJ, Williams JS, Egede L. Pathways between food insecurity and glycemic control in individuals with type 2 diabetes. Public Health Nutr. 2018;21(17):3237-44. https://doi.org/10.1017/ S1368980018001908 Well-conducted structural equation modeling study examining pathways that explain the association between food insecurity and glycemic control.

27. Murillo R, Reesor LM, Scott CW, Hernandez DC. Food insecurity and pre-diabetes in adults: race/ethnic and sex differences. Am J Health Behav. 2017;41(4):428-36. https://doi.org/10.5993/AJHB. 41.4.7.

28. Vaccaro JA, Huffman FG. Sex and race/ethnic disparities in food security and chronic diseases in U.S. older adults. Gerontol Geriatr Med. 2017;3. https://doi.org/10.1177/2333721417718344.

29. Abdurahman AA, Chaka EE, Nedjat S, Dorosty AR, Majdzadeh R. The association of household food insecurity with the risk of type 2 diabetes mellitus in adults: a systematic review and meta-analysis. Eur J Nutr. 2019;58(4):1341-50. https://doi.org/10.1007/s00394018-1705-2.

30. Silbert R, Salcido-Montenegro A, Rodriguez-Gutierrez R, Katabi A, McCoy RG. Hypoglycemia among patients with type 2 diabetes: epidemiology, risk factors, and prevention strategies. Curr Diab Rep. 2018;18(8):53. https://doi.org/10.1007/s11892-018-1018-0.

31. Tait CA, L'Abbé MR, Smith PM, Rosella LC. The association between food insecurity and incident type 2 diabetes in Canada: a population-based cohort study. PLoS One. 2018;13(5). https://doi. org/10.1371/journal.pone.0195962 Notable for its longitudinal design, this study finds an association between food insecurity and incident diabetes, overcoming the issue of cross-sectional study design and examination of prevalent diabetes noted in other studies.

32. Berkowitz SA, Karter AJ, Corbie-Smith G, Seligman HK, Ackroyd SA, Barnard LS, et al. Food insecurity, food "deserts," and glycemic control in patients with diabetes: a longitudinal analysis. Diabetes Care. 2018;41(6):1188-95. https://doi.org/10.2337/dc171981.

33. Shalowitz MU, Eng JS, McKinney CO, et al. Food security is related to adult type 2 diabetes control over time in a United States safety net primary care clinic population. Nutr Diabetes. 2017;7(5):e277. https://doi.org/10.1038/nutd.2017.18.

34. Schroeder EB, Zeng C, Sterrett AT, Kimpo TK, Paolino AR, Steiner JF. The longitudinal relationship between food insecurity in older adults with diabetes and emergency department visits, hospitalizations, hemoglobin A1c, and medication adherence. J Diabetes Complicat. 2019;33(4):289-95. https://doi.org/10.1016/j. jdiacomp.2018.11.011.

35. Blitstein JL, Lazar D, Gregory K, McLoughlin C, Rosul L, Rains C, et al. Foods for health: an integrated social medical approach to food insecurity among patients with diabetes. Am J Health Promot. 2021 Mar;35(3):369-76. https://doi.org/10.1177/ 0890117120964144.

36. Berkowitz SA, Delahanty LM, Terranova J, Steiner B, Ruazol MP, Singh R, et al. Medically tailored meal delivery for diabetes patients with food insecurity: a randomized cross-over trial. J Gen Intern Med. 2019;34(3):396-404. https://doi.org/10.1007/s11606-0184716-z.

37. Ferrer RL, Neira L-M, De Leon Garcia GL, Cuellar K, Rodriguez J. Primary care and food bank collaboration to address food insecurity: a pilot randomized trial. Nutr Metab Insights. 2019;12: 1178638819866434. https://doi.org/10.1177/1178638819866434.

38.• Seligman HK, Smith M, Rosenmoss S, Marshall MB, Waxman E. Comprehensive diabetes self-management support from food banks: a randomized controlled trial. Am J Public Health. 2018;108(9):1227-34. https://doi.org/10.2105/AJPH.2018. 304528 Large, well-conducted randomized clinical trial that 
explicitly addressed food insecurity and diabetes selfmanagement

39. Venci BJ, Lee S-Y. Functional limitation and chronic diseases are associated with food insecurity among U.S. adults. Ann Epidemiol. 2018;28(3):182-8. https://doi.org/10.1016/j.annepidem.2018.01. 005.

40. Charkhchi P, Fazeli Dehkordy S, Carlos RC. Housing and food insecurity, care access, and health status among the chronically ill: an analysis of the behavioral risk factor surveillance system. J Gen Intern Med. 2018;33(5):644-50. https://doi.org/10.1007/s11606017-4255-z.

41. Hummel SL, Wahida K, Gillespie Brenda W, et al. Home-delivered meals postdischarge from heart failure hospitalization. Circ Heart Fail. 2018;11(8):e004886. https://doi.org/10.1161/ CIRCHEARTFAILURE.117.004886 Intriguing smaller-scale randomized clinical trial examining the use of home-delivered meals after heart failure admission.

42. Banerjee T, Crews DC, Wesson DE, et al. Food insecurity, CKD, and subsequent ESRD in US adults. Am J Kidney Dis. 2017;70(1): 38-47. https://doi.org/10.1053/j.ajkd.2016.10.035 Important longitudinal study that finds an association between food insecurity and subsequent end-stage renal disease among those with chronic kidney disease.

43. Crews DC, Novick TK. Social determinants of CKD hotspots. Semin Nephrol. 2019;39(3):256-62. https://doi.org/10.1016/j. semnephrol.2019.02.003.

44. CDC - NCHS - National Center for Health Statistics. Published February 26, 2021. Accessed February 27, 2021. https://www. cdc.gov/nchs/index.htm

45. Nguyen BT, Ford CN, Yaroch AL, Shuval K, Drope J. Food security and weight status in children: interactions with food assistance programs. Am J Prev Med. 2017;52(2S2):S138-44. https://doi.org/ 10.1016/j.amepre.2016.09.009.

46. Orr CJ, Ravanbakht S, Flower KB, Yin HS, Rothman RL, Sanders LM, et al. Associations between food insecurity and parental feeding behaviors of toddlers. Acad Pediatr. 2020;20(8):1163-9. https:// doi.org/10.1016/j.acap.2020.05.020.

47. Baer TE, Scherer EA, Richmond TK, Fleegler EW, Hassan A. Food insecurity, weight status, and perceived nutritional and exercise barriers in an urban youth population. Clin Pediatr (Phila). 2018;57(2):152-60. https://doi.org/10.1177/0009922817693301.

48. Poulsen MN, Bailey-Davis L, Pollak J, Hirsch AG, Schwartz BS. Household food insecurity and home food availability in relation to youth diet, body mass index, and adiposity. J Acad Nutr Diet. 2019;119(10):1666-75. https://doi.org/10.1016/j.jand.2019.01. 001.

49. Drennen CR, Coleman SM, de Ettinger Cuba S, et al. Food insecurity, health, and development in children under age four years. Pediatrics. 2019;144(4). https://doi.org/10.1542/peds.2019-0824.

50. Oberle MM, Romero Willson S, Gross AC, Kelly AS, Fox CK. Relationships among child eating behaviors and household food insecurity in youth with obesity. Child Obes. 2019;15(5):298305. https://doi.org/10.1089/chi.2018.0333.

51. Zhu Y, Mangini LD, Hayward MD, Forman MR. Food insecurity and the extremes of childhood weight: defining windows of vulnerability. Int J Epidemiol. 2020;49(2):519-27. https://doi.org/10. 1093/ije/dyz233.

52. Lee AM, Scharf RJ, DeBoer MD. Association between kindergarten and first-grade food insecurity and weight status in U.S. children Nutrition. 2018:51-52-1-5. https://doi.org/10.1016/j.nut.2017.12. 008.

53. Lohman BJ, Neppl TK, Lee Y, Diggs ON, Russell D. The association between household food insecurity and body mass index: a prospective growth curve analysis. J Pediatr. 2018;202:115120.e1. https://doi.org/10.1016/j.jpeds.2018.05.052.

54. South AM, Palakshappa D, Brown CL. Relationship between food insecurity and high blood pressure in a national sample of children and adolescents. Pediatr Nephrol. 2019;34(9):1583-90. https://doi. org/10.1007/s00467-019-04253-3.

55. Lee AM, Scharf RJ, Filipp SL, Gurka MJ, DeBoer MD. Food insecurity is associated with prediabetes risk among U.S. adolescents, NHANES 2003-2014. Metab Syndr Relat Disord. 2019;17(7):347-54. https://doi.org/10.1089/met.2019.0006.

56. Thomas MMC, Miller DP, Morrissey TW. Food insecurity and child health. Pediatrics. 2019;144(4). https://doi.org/10.1542/peds. 2019-0397.

57. Clemens KK, Le B, Anderson KK, Shariff SZ. Childhood food insecurity and incident diabetes: a longitudinal cohort study of 34 042 children in Ontario, Canada. Diabet Med. 2020:e14396. https:// doi.org/10.1111/dme.14396.

58. Mendoza JA, Haaland W, D'Agostino RB, Martini L, Pihoker C, Frongillo EA, et al. Food insecurity is associated with high risk glycemic control and higher health care utilization among youth and young adults with type 1 diabetes. Diabetes Res Clin Pract. 2018;138:128-137. doi:10.1016/j.diabres.2018.01.035. Important studying finding association between food insecurity and glycemic control in youth and young adults with type 1 diabetes.

59. Ratcliffe C, McKernan S-M, Zhang S. How much does the supplemental nutrition assistance program reduce food insecurity? Am J Agric Econ. 2011;93(4):1082-98. https://doi.org/10.1093/ajae/ aar026.

60. Keith-Jennings B, Llobrera J, Dean S. Links of the supplemental nutrition assistance program with food insecurity, poverty, and health: evidence and potential. Am J Public Health. 2019;109(12): 1636-40. https://doi.org/10.2105/AJPH.2019.305325.

61. Gundersen C, Ziliak JP. Food insecurity and health outcomes. Health Aff (Millwood). 2015;34(11):1830-9. https://doi.org/10. 1377/hlthaff.2015.0645.

62. About WIC- How WIC Helps | USDA-FNS. Accessed February 27, 2021. https://www.fns.usda.gov/wic/about-wic-how-wic-helps

63. Benefits of School Lunch. Food Research \& Action Center. Accessed February 27, 2021./programs/national-school-lunch-program/benefits-school-lunch

64. State Guidance on Coronavirus Pandemic EBT (P-EBT)|USDAFNS. Accessed February 27, 2021. https://www.fns.usda.gov/snap/ state-guidance-coronavirus-pandemic-ebt-pebt

65. More Adequate SNAP Benefits Would Help Millions of Participants Better Afford Food | Center on Budget and Policy Priorities. Accessed February 27, 2021. https://www.cbpp.org/ research/food-assistance/more-adequate-snap-benefits-wouldhelp-millions-of-participants-better

66. Venkataramani AS, O'Brien R, Tsai AC. Declining life expectancy in the United States: the need for social policy as health policy. JAMA. 2021;325(7):621-2. https://doi.org/10.1001/jama.2020. 26339.

67. Coleman-Jensen A, Rabbitt MP, Gregory CA, Singh A. Household food security in the United States in 2019. Accessed February 27, 2021. http://www.ers.usda.gov/publications/pub-details/?pubid= 99281

Publisher's Note Springer Nature remains neutral with regard to jurisdictional claims in published maps and institutional affiliations. 